Regular Research Article

\title{
Productivity and Cost Analysis of Forest Harvesting Operation in Matang Mangrove Forest, Perak, Malaysia
}

\author{
Albert Empawi Tindit ${ }^{1}$, Seca Gandaseca ${ }^{2}$ *, Laurna Nyangon ${ }^{3}$ and Ahmad Mustapha Mohamad \\ Pazi $^{4}$ \\ 1,2,3,4 Department of Forest Production, Faculty of Forestry, Universiti Putra Malaysia, 43400 Serdang, \\ Selangor Darul Ehsan Malaysia. \\ 1 aempawi@gmail.com \\ 2 seca@upm \\ 3 laurnanyangon@gmail.com \\ 4 muss.pazi@gmail.com \\ * Correspondence author: seca@upm.edu.my; Tel.: +60194830370
}

\begin{abstract}
Matang Mangrove Forest is under systematic management since 1902 and still considered as the best managed mangrove forest in the world. This research was conducted to measure the time and productivity of forest harvesting operation and also to analyze the cost and revenue of mangrove forest harvesting operation at Matang mangrove forest. This project had been carried out in cooperation with Seri Sepetang Enterprise, one of the harvesting licenses in Kuala Sepetang, Perak. Data collections were taken in every station starting from standing tree until to the Kiln-Drying jetty. The data then calculated by using the formulas of productivity and cost analysis. As the result, the productivity for felling, bucking and debarking, the manual skidding using wheel-barrow and the water transportation are 1.84 tan/hour, 3.82 $\tan /$ hour and $4.64 \tan /$ hour respectively. The cost for each operation of 9 tan log volume for felling, bucking and debarking, the manual skidding using wheel-barrow and the water transportation are RM $56.88, \mathrm{RM} 10.80$ and RM 36.72 respectively. As the revenue, the company paid RM 260 per $9 \tan$ of log for the in-forest operation (felling, manual skidding and loading to the ship) and pay RM 80 per 9 tan for the water transportation, and they gained the net profit of RM 192.32 and RM 43.28 respectively. The average of forest harvesting operation is twice operation in a day (equal with $2 \times 9$-ton volume of log production a day), so they will gain a double profit. In conclusion, the forest harvesting operation is sustainably managed for supplying the raw material of charcoal industries in Matang mangrove forest. Since, they work manually and spend much energy in this forest harvesting operation, so for further study it recommends to conduct the ergonomics evaluation during forest harvesting operation at Matang Mangrove Forest.
\end{abstract}

Keywords: Time Study; Productivity; Unit Cost; Cost Analysis; Mangrove; Forest Harvesting

\section{Introduction}

Matang mangrove forest known as one of the most sustainable management system around the world especially in forestry resources and have an important role in supplying constant yield of forest product (Jusoff, 2009). Borges et al. (2003) reported that mangrove is among the most productive coastal intertidal ecosystem in the world, confined to the tropics and subtropics, which dominate approximately $75 \%$ of the world's coastline between $250 \mathrm{~N}$ and $250 \mathrm{~S}$. Indonesia, Thailand, Malaysia, and India are such country in Asia where the mangrove population distributed (Alongi, 2008). Matang Mangrove Forest is under systematic management since 1902 and still considered as the best managed mangrove forest in the world. The present study on silvimetrics assessed the ongoing forest management, which includes a first thinning after 15 years, a second 
thinning after 20 years and clear-felling of 30-year old forest blocks, for its efficiency and productivity in comparison to natural mangroves (Goessens et al., 2014).

Forest harvesting is among the contributor to the socioeconomic activities in Matang mangrove forest beside aquaculture, agriculture and ecotourism. The main product of forest harvesting in mangrove forests are fuel wood, charcoal, and poles. Mangrove forest is the most productive ecosystem for services to the environment and people as the demand is increasing nowadays (WWF, 2013). Forest harvesting refers to the process of cutting down trees and the process of delivering them to a mill or log pond. Most forest operation will aim for high productivity and gain high profit. What make the forest harvesting is challenging when it comes to the term of efficient in productivity and cost? Each forest operation has different types of system they used depends on the area of the operation done. Besides that, the productivity incurred is less compare to other type forest production like dipterocarp forest, hill forest and others. Due to the challenge in forest harvesting activities, work study including time studies and productivity studies can improve the work performance to increase the efficiency and effectiveness.

Most of the works or operations are manually done by human and the use of machine is very limited due to the conditions in the mangrove forest. The tides also give effect to the operation hour. If all of these restraints are not well managing into an efficient forest operation system, both productivity and efficient cost of the operation are cannot be achieved. This research was focused on the time study, productivity and total cost of the mangrove forest harvesting operation for a certain number of logs.

\section{Materials and Methods}

\subsection{Study Site}

This research project was conducted in one of the forest harvesting area at Matang Mangrove Forest, Perak. Seri Sepetang Enterprise is one of the charcoal's producers at Matang Mangrove Forest, where this research project had been carried out; in one of their license compartment. The Matang Mangrove Forest Reserve located on the northwest coast of Peninsular Malaysia as shown in Figure 1.
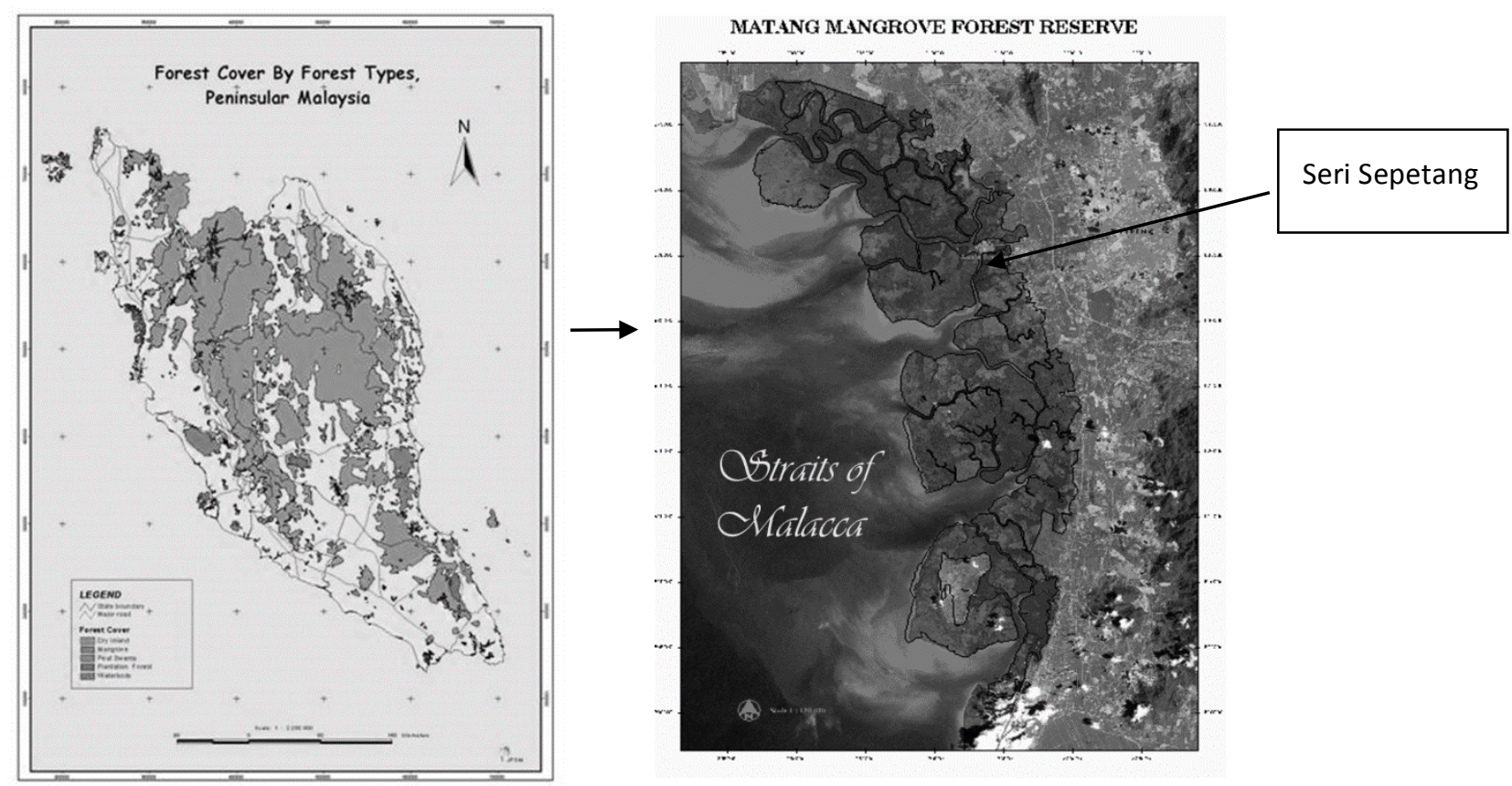

Figure 1: The Study Site at Matang Mangrove Forest Reserve 


\subsection{Work Element and Data Collection of Forest Harvesting Operation}

Figure 2 shows the forest harvesting operation at Matang Mangrove forest. This operation consists of 3 main operations, such as: i) felling, bucking and debarking; ii) Loading, manual skidding using wheel-barrow and unloding at the log pond at the river-side; and iii) Loading on boat, water transportation, and unloading log at the Kiln-drying jetty.

Figure 2: Work Element of Forest Harvesting Operation

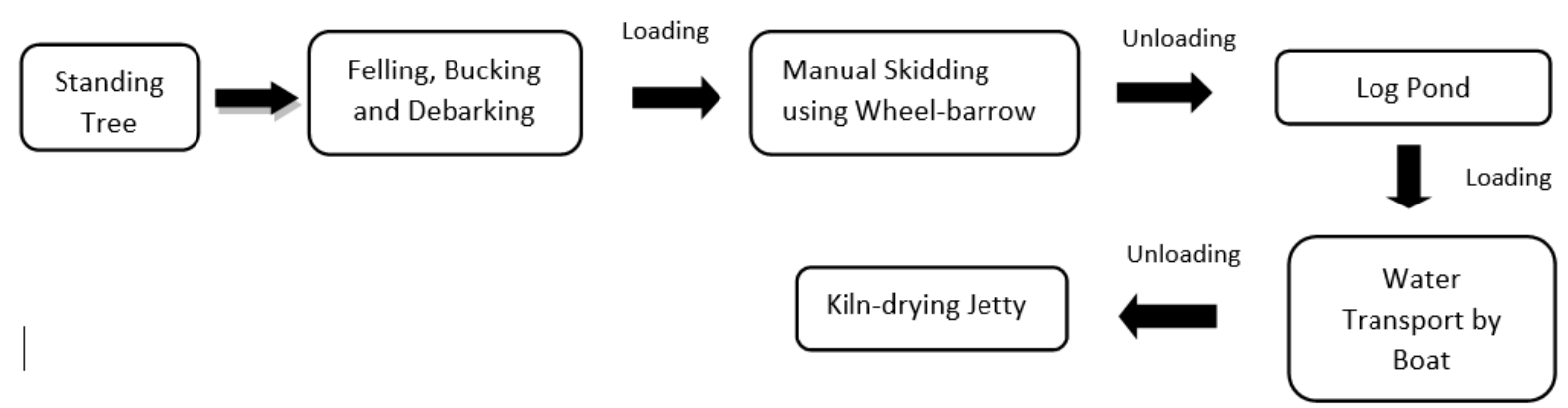

Usually on bucking activity, one felled tree is divided into 11 to 12 small logs, with length of each log is $1.6 \mathrm{~m}$ and has the average weight of $0.07 \mathrm{ton} / \mathrm{log}$. Then about 5-6 logs are loaded on the wheel-barrow per trip. Data collections were taken in every station starting from standing tree, felling, bucking and debarking, manual skidding, loading on the boat, water transport and unloading at the Kiln-Drying jetty.

\subsection{Time Study and Productivity of Machine/Equipment}

Time consumption and productivity during forest harvesting operation at Matang Mangrove forest was recorded using stop watch, digital camera and distance tape. This baseline data was used for determining the time consumption of each element of work by following certain formula.

\subsubsection{Time Study}

Time study is the systematic observation of the time consumption to define work performance during harvesting activities (Currie \& Faraday, 1989). Work measurement technique for recording the times and rates of working for the elements of a specified job carried out under specified conditions and for analyzing the data to obtain the time necessary for carrying out the job at a defined level of performance. This baseline time data was used for determining the time consumption of each element of work by following certain formula, including time for chainsaw, skidding, loading and unloading, and hauling (water transport) (FAO, 1992).

For time study, the time taken for each activity was recorded based on the actual time, speed or effort of the worker during their work daily. For example, the time of felling, bucking and debarking were recorded once the feller start the chainsaw and the time was stopped until all these three elements of operation were done. It was the same procedure also for the other two main operations where 3 replications were done for each processed.

\section{- Felling, Bucking and Debarking Time}

Felling production is estimated by dividing the volume per cycle by the minutes per cycle. The time per Tree for felling, bucking and debarking, follow the equation 1:

$$
T=a 1+b 1+c 1
$$


where; $\mathrm{a}$ is the felling time per cycle, $\mathrm{b}$ is the bucking time per cycle and $\mathrm{c}$ is the debarking time per cycle

\section{- Skidding Time}

Skidding production is estimated by dividing the volume per load by the time per around trip. The round-trip time, $T$, is the sum of the time for travel unloaded, hooking, travel loaded, and unhooking, follow the equation 2 :

$\mathrm{T}=\mathrm{a} \mathrm{N}+\mathrm{b} 1 \times 1+\mathrm{b} 2 \times 2$

where; $a$ is the combined time for hooking and unhooking per log, b1 is the minutes per meter for unloaded travel, b2 is the minutes per meter for loaded travel, $x 1$ is the distance from the landing to load pickup point and $\mathrm{x} 2$ is the distance from the load pickup point to the landing.

\section{- Loading and Unloading Time}

Loading production is estimated by dividing the volume per cycle by the minutes per cycle. The time per log for loading single logs, follow the equation 3 :

$\mathrm{T}=\mathrm{a} 1$ and $\mathrm{T}=\mathrm{b} 1$

where; $\mathrm{a}$ is the loading time per cycle and $\mathrm{b}$ is the loading time per cycle.

\subsubsection{Productivity:}

The productivity (P) was calculated according to equation 4 (Norizah, 2012):

$\mathrm{P}=$ Volume $/$ Time

where; $\mathrm{V}=$ volume per $\log \left(\mathrm{m}^{3}\right)$

\subsection{Cost Analysis of Logging Operation at Matang Mangrove Forest}

\subsubsection{Machine Rate}

The machine rates for a chainsaw, a manual skidding using wheel barrow and water transport by boat are shown on Table 1 (FAO, 1992).

Table 1: Cost Component and Equations for determining the Machine Rate.

\begin{tabular}{|c|c|c|}
\hline No. & Cost Component & Equation $5-12$ \\
\hline 1 & Depreciation & $=$ (delivery cost $) \times 0.9 /$ life in hours \\
\hline 2 & Interest & $=($ delivery cost $) \times 0.6 \times 10 \% /$ average hours per year \\
\hline 3 & Insurance & $=($ delivery cost $) \times 0.6 \times 3 \% /$ average hours per year \\
\hline 4 & Taxes & $=($ delivery cost $) \times 0.6 \times 2 \% /$ average hours per year \\
\hline 5 & Labor & $\begin{array}{l}=\text { Labor cost per year } x(1+f) / \text { average hours per year where: } f \text { is } \\
\text { social costs of labor as decimal }\end{array}$ \\
\hline 6 & Fuel & $\begin{array}{l}=0.2 \times \text { GHP X LF X CL; Where: GHP is gross engine horsepower, CL is cost } \\
\text { per liter for fuel, and LF is load factor }\end{array}$ \\
\hline 7 & Oil and Grease & $=0.1 \times$ fuel cost \\
\hline 8 & $\begin{array}{l}\text { Servicing and } \\
\text { Repair }\end{array}$ & $=1.0 \times$ depreciation \\
\hline 9 & Others & Certain contingency amount needed \\
\hline
\end{tabular}


Although the machine rates share the same general format, there is flexibility to represent costs that are specific to the machine type, particularly in the calculation of the operating costs as shown on Table 1.

\subsubsection{Cost Analysis}

For analysis of the operation cost, first is to determine the unit cost (RM/ton), then if for the cost operation is depending on how many log volume produced on certain time or day or period (FAO, 1992)

\section{- Unit Cost}

The unit cost of machine is the total expenditure by a machine to produce one unit of production, so it is equal with machine rate divide by productivity, as follow the equation 13:

Unit Cost $=$ Machine Rate / Productivity, where: Unit Cost is in RM/ton .

\section{- Cost Operation}

The cost operation is the expenses which are related to the operation to produce certain units of production, and it is calculated follow the equation 14 :

Cost Operation $(\mathrm{RM})=$ Unit Cost $(\mathrm{RM} /$ ton $) \times$ Volume of Log Production (ton)

\section{Results and Discussion}

\subsection{Time and Productivity}

Table 2 shows that the time and productivity of Matang mangrove forest harvesting operation after the study of time and productivity were conducting based on the worker's daily work. Repetition of each operation was done as much as 3 times to get the average time of the operations. For felling, bucking and debarking, the systems were operated by chainsaw where after the allowable tree was cut down, it was continued with bucking. Bucking was the process where the tree was cut according to the predetermined length by Forestry Department, 1.6 meter. A man-made pole which length $1.6 \mathrm{~m}$ was used to mark the measure by an axe first and then it can cut into $1.6 \mathrm{~m}$ length log. At the same time, debarking process was done where the bark was removed using man-made hammer, which made from the mangrove root. All these processes were done continuously by 2 or 3 man.

In Matang Mangrove forest operation, the buttress of the tree was left or not removed for many purposes. The purposes were to maintain the stability of the soil in the operation area after harvested and also as the shield to the new seedling for re-plantation. The buttress cannot be destroyed directly or been removed because it was the habitat of many life in mangrove forest.

Table 2: Time Study and Productivity of Forest Operation at Matang Mangrove Forest

\begin{tabular}{lll}
\hline Operations & Time (Minutes) & Productivity (Ton/hour) \\
\hline Felling, Bucking, Debarking & 28.67 & 1.84 \\
Manual Skidding (Wheel Barrow) & 6.60 & 3.82 \\
Water Transportation & 116.4 & 4.64 \\
\hline TOTAL & 151.67 & 10.22 \\
\hline
\end{tabular}


Then, manual skidding was done by using man-made wheel barrow. A wheel barrow can load around 5 to $6 \log$ that had cut into $1.6 \mathrm{~m}$ length. The wheel barrow then push on the track which specially made to skid it from the felling area to the log pond. The idea of using wheel barrow in mangrove forest harvesting was due to the condition of soil is soft which cause the potential development of flotation vehicles suited to the operations without road constructions (Silversides and Sundberg, 2013). For water transportation, the log transport by boat was the best way to access the mangrove operation area. A boat can load $9 \tan$ of log per trip which was equal to $130-$ 150 logs. The boat was powered by Yanmar engine that can speed $9 \mathrm{~km} / \mathrm{hour}$.

\subsection{Cost Analysis of Forest Operation at Matang Mangrove Forest}

\subsubsection{Machine Rate}

The result of machine rates for a chainsaw, manual skidding using wheel-barrow and the water transportation by boat are shown on Table 3. The economic life time is the period over which the equipment can operate at an acceptable operating cost and productivity (FAO, 1992). In this study, the economic life time for chainsaw, wheel-barrow and boat are 5,000 hours, 5,000 hours and 15000 hours, respectively.

Table 3: Cost Component and Machine/Equipment Rate (RM/hour)

\begin{tabular}{lllll}
\hline \multirow{2}{*}{ No. } & Cost Component & \multicolumn{3}{c}{ Rate of Machine/Equipment } \\
& & \multicolumn{3}{c}{ (RM/hour) } \\
\cline { 3 - 5 } & & Chainsaw & Wheel Barrow & Boat \\
\hline 1 & Depreciation & $0.45 \pm 0.08$ & $0.015 \pm 0.01$ & $0.9 \pm 0.21$ \\
2 & Interest & $0.15 \pm 0.05$ & - & $1.8 \pm 0.42$ \\
3 & Insurance & $0.045 \pm 0.016$ & - & $0.54 \pm 0.13$ \\
4 & Taxes & $0.03 \pm 0.01$ & - & $0.36 \pm 0.08$ \\
5 & Labor & $3.58 \pm 0.72$ & $3.58 \pm 0.27$ & $3.58 \pm 0.26$ \\
6 & Fuel & $4.48 \pm 1.39$ & - & $8.06 \pm 0.32$ \\
7 & Oil and Grease & $0.448 \pm 0.139$ & - & $0.806 \pm 0.032$ \\
8 & Servicing and Repair & $0.45 \pm 0.08$ & 1 & $0.9 \pm 0.21$ \\
9 & Other & 2 & - & 2 \\
\hline & Total & $11.63 \pm 2.17$ & $4.6 \pm 0.47$ & $18.95 \pm 0.13$ \\
\hline
\end{tabular}

Since, the manual skidding using wheel-barrow, so the equation for interest, insurance, taxes, fuel, oil and grease are not taken into calculation, and the servicing and repair in average is about RM 1 per hour.

\subsubsection{Cost Analysis}

Table 4 shows that the cost analysis forest operation in the mangrove forest per trip. A boat can transport of 9 ton of log from the log pond to the jetty of the Kiln-Drying. As shown on the Table 2, the forest operation in the forest was handled by 2-3 of workers. The cost operation from felling until manual skidding is RM 77.86, while they were paid RM 260 per 9 ton for these forest operations. They gained RM192.32 for each trip or 9 ton of log started from felling until loaded the log into the boat. So, each worker gained approximately RM64.11/person (if done by 3 workers) and RM96.16/person (if only done 2 workers). By the way, a boatman gained RM43.28 per trip for transported the log from log pond to the Kiln-Drying jetty. The boatman job was just transported 
the log with his own boat to the jetty, meanwhile the unloading and loading of log were handled by other persons.

Table 4: Cost Analysis of Forest Operation (per $9 \tan$ of log volume) at Matang Mangrove Forest

\begin{tabular}{llllll}
\hline Operations & $\begin{array}{l}\text { Unit Cost } \\
\text { (RM/ton) }\end{array}$ & $\begin{array}{l}\text { Log Volume } \\
\text { (ton) }\end{array}$ & $\begin{array}{l}\text { Cost } \\
\text { RM/9 ton }\end{array}$ & $\begin{array}{l}\text { Wages } \\
\text { per 9 ton }\end{array}$ & $\begin{array}{l}\text { Net Profit } \\
\text { per 9 ton }\end{array}$ \\
\hline Felling, Bucking, Debarking & 6.32 & & 56.88 & 260 & 192.32 \\
Manual Skidding & 1.20 & 9 & 10.80 & & \\
Water Transportation & 4.08 & & 36.72 & 80 & 43.28 \\
\hline TOTAL & & & 104.40 & 340 & 235.60 \\
\hline
\end{tabular}

Note: One wage per 9 ton production of forest operations (felling, bucking, debarking \& skidding).

Based on the Table 4, this forest harvesting operation was well managed in term of the net profit of the workers gained because they saved more profit compare to the cost operation. The time study and productivity of forest operation at Matang mangrove forest were showed that they managed the forest operation efficiently where as we know that mangrove forest operation was challenging in term of hard to access by machinery. So, they had to handle all of the works there manually and this proved that they were very experienced and strong workers. Many studies were reported that the skidding distance is the most significant variable for the productivity (Kluender et al. 1997; Wang et al. 2004). It shows that the workers here were efficiently managed their work even without the help of machine to do the hard work like the skidding. This also proved that they managed to settle down their work in a short time by only depend fully on their own strengths and competences, based on the time study result. They also proved their works were managed well when they had to race with the tide phenomenon in the mangrove forest to settle down their work in time to avoid losses.

According to Naghdi (2005), there were some variables that can influenced the time consumption of skidding for examples, not well managed felling time (felling just a few days before skidding), skid trail with poor design and also workers were keeping in pressure. This matter was not just only affect the skidding process, but it was also affect the other activities productivity and time consumption which lead to loss. Nurminen et. al (2006) were also said that the productivity and time consumption of harvesting were depend on the conditions of the standing tree, the skills of operator and the working techniques. Moreover, this mangrove forest operation was also managed to avoid unnecessary loss for each of their works, even they managed to gain more profit compare to the cost operation they had to bear. It was proved after the analysis of cost and revenue had shown a great net profit for the forest operation. In conclusion, Seri Sepetang Enterprise had produced a good productivity and managed the cost operation well.

Since, they work manually and spend much energy in this forest harvesting operation, so for further study it recommends to conduct the ergonomics evaluation during forest harvesting operation at Matang Mangrove Forest. Besides that, this study was conducted to provide a baseline for the time study and productivity in the mangrove forest operation since that nowadays there were a few areas only that still actively operate in mangrove area in Malaysia. In the future, maybe this project can be the benchmarking for other mangrove forest operation for comparison on the efficiency of the system they use, maybe with new technology and future operation system.

\section{Conclusions}

In Matang mangrove forest, the forest harvesting operation is sustainably managed for supplying the raw material of charcoal industries. In this study, the productivity for felling, bucking and debarking, the manual skidding using wheel-barrow and the water transportation are 1.84 ton/hour, 3.82 ton/hour and 4.64 ton/hour respectively. All these operations were done continuously by 2 or 3 workers. The cost operations per 9 -ton log volume for felling, bucking and 
debarking, the manual skidding using wheel-barrow and the water transportation are RM56.88, RM10.80 and RM36.72 respectively. As the revenue, the company paid RM260 per 9 ton of log for the in-forest operation (felling, manual skidding and loading to the ship) and paid RM80 per 9 ton for the water transportation, and they gained the net profit of RM192.32 and RM43.28 respectively. The average of forest harvesting operation is twice operation in a day (equal with $2 \mathrm{x}$ 9 -ton volume of log production a day), so they will gain a double profit. Since, they work manually and spend much energy in this forest harvesting operation, so for further study it recommends to conduct the ergonomics evaluation during forest harvesting operation at Matang Mangrove Forest.

Author Contributions: Albert Empawi Tindit and Seca Gandaseca conceived and designed the experiments; Albert Empawi Tindit, Seca Gandaseca, Laurna Nyangon and Ahmad Mustapha Mohamad Pazi performed the experiments, analyzed data and contributed reagents/material/analysis tools; Albert Empawi Tindit and Seca Gandaseca wrote the paper.

\section{Acknowledgments}

The appreciation goes to Forestry Department of Kuala Sepetang for providing the study site and data collection in Matang Mangrove Forest. I am so grateful to Faculty of Forestry for providing laboratory facilities and staff during this study.

\section{References}

Alongi, D. M. (2008). Mangrove forests: resilience, protection from tsunamis, and responses to global climate change. Estuarine, Coastal and Shelf Science, 76(1), 1-13.

Borges, A. V., Djenidi, S., Lacroix, G., Théate, J., Delille, B., \& Frankignoulle, M. (2003). Atmospheric $\mathrm{CO} 2$ flux from mangrove surrounding waters. Geophysical Research Letters, 30(11).

Currie, R.M. \& Faraday, J.E., 1989. Work Study. Pitman Publishing, London, UK, pp. 47-48.

FAO, (1992). Cost Control in Forest Harvesting and Road Construction. ISBN 92-5-103161-4. Publication Division, FAO, Rome, Italy.

Goessens, A., et al., (2014). Is Matang Mangrove Forest Sustainably Rejuvenating after More than a Century of Conservation and Harvesting Management?. Journal of Plos One. http://dx.doi.org/10.1371/journal.pone.0105069.

Kluender, R., Lortz, D., McCoy, W., Stokes, B., \& Klepac, J. (1997). Productivity of rubber-tired skidders in southern pine forests. Forest Products Journal, 47(11/12), 53.

Naghdi, R., RAFATNIA, N., Sobhani, H., Jalali, G., \& Hosseini, M. (2005). A survey of the efficiency of Timberjack $\mathrm{C} 450$ wheeled skidder in Shafaroud forests in Guilan province.

Nurminen, T., Korpunen, H., \& Uusitalo, J. (2006). Time consumption analysis of the mechanized cut-to-length harvesting system. Silva Fennica, 40(2), 335.

Norizah, K., Hasmadi, M. I., Kamaruzaman, J. (2012). Operational efficiency of rimbaka timber harvester in hilly tropical forest. Journal of Tropical Forest Science. Vol 24(3), 368-378.

Silversides, C. R., \& Sundberg, B. (2013). Operational Efficiency in Forestry: Vol. 2: Practice (Vol. 32). Springer Science \& Business Media.

Wang, J., Long, C., \& McNeel, J. (2004). Production and cost analysis of a feller-buncher and grapple skidder in central Appalachian hardwood forests. Forest products journal, 54(12), 159.

WWF (World Wide Fund). (2013). Mangrove Forest. Retrieved from http://www.wwf.org.my/. in September 8, 2015. 